\title{
Hormone resistance in prostate cancer
}

\author{
Mary Josephine P. Pilat ${ }^{1}$, Jeffery M. Kamradt ${ }^{1}$ and Kenneth J. Pienta ${ }^{1,2}$ \\ ${ }^{1}$ Department of Internal Medicine, Division of Hematology/Oncology, Comprehensive Cancer Center, \\ ${ }^{2}$ Department of Surgery, Section of Urology, University of Michigan, Ann Arbor, Michigan, USA
}

Key words: prostate cancer, hormone-refractory, androgen-independent, androgen receptor

Prostate cancer is the most frequently diagnosed cancer and the second leading cause of cancer death in men in the United States. Projected estimates for 1999 indicate that there will be approximately 179,300 newly diagnosed prostate cancers and 37,000 men will die from this disease [1]. While organ confined prostate cancer is potentially curable with radical prostatectomy and/or radiation, treatment of locally advanced or metastatic disease remains palliative. In those symptomatic patients with newly diagnosed metastatic prostate cancer, androgen deprivation is the front-line treatment. Androgen ablation therapy is useful and results in stabilization or regression of disease in approximately $80 \%$ of patients. Unfortunately, most of these patients will fail and inevitably progress to hormone-independent disease. In this review the authors will attempt to summarize the salient points which may contribute to the mechanism of hormone resistance as well as briefly review the current treatment regimens for patients with hormone refractory prostate cancer.

\section{Potential mechanisms of hormone resistance in prostate cancer}

The events which characterize the progression from the hormone dependent to the hormone independent state in prostate cancer remains unclear (Figure 1). One of the central questions in the study of androgenindependent prostate cancer concerns the point at which androgen-independent cells arise. Two main theories have been proposed. The first theory suggests that androgen independence arises as a consequence of androgen deprivation therapy. This approach proposes that prostate cancer begins as a collection of androgen-dependent cells and only as a result of androgen deprivation do androgen-resistant cells arise. This mechanism of resistance is analogous to bacteria gaining resistance to antimicrobials. The second approach suggests that androgen resistant cells are present at diagnosis. In this case, androgen deprivation creates an environment that allows only the proliferation of androgen-resistant cells which eventually become the dominant cell type [2].

This second approach has been validated with experimental evidence from two animal models. Isaacs and Coffey demonstrated in a series of experiments using the Dunning 3327-H adenocarcinoma model that selective growth of androgen-resistant cells already present at the initiation of androgen depletion is the mechanism for the development of androgen resistance [2]. They hypothesized that if a tumor is initially composed of a heterogeneous population of cells in terms of androgen sensitivity, then random tumor tissue samples would demonstrate a varied growth pattern when implanted into castrated animals. On the other hand, if the tumor is composed of only androgen-sensitive cells which through adaptation became androgen resistant, the growth rates would be similar. They found a tremendous variation in the growth rates of the implanted samples, suggesting the original tumor was initially heterogeneous in terms of androgen sensitivity. Further evidence that supports this is the development of the transgenic mouse prostate adenocarcinoma model (TRAMP) [3]. TRAMP mice spontaneously develop high-grade prostate intraepithelial neoplasia and welldifferentiated prostate cancer by 10-12 weeks. Sixtyfive percent of mice castrated at 12 weeks of age demonstrated an initial reduction followed by a rapid regrowth of an androgen-independent tumor [4]. This rapid regrowth again supports the concept that the 


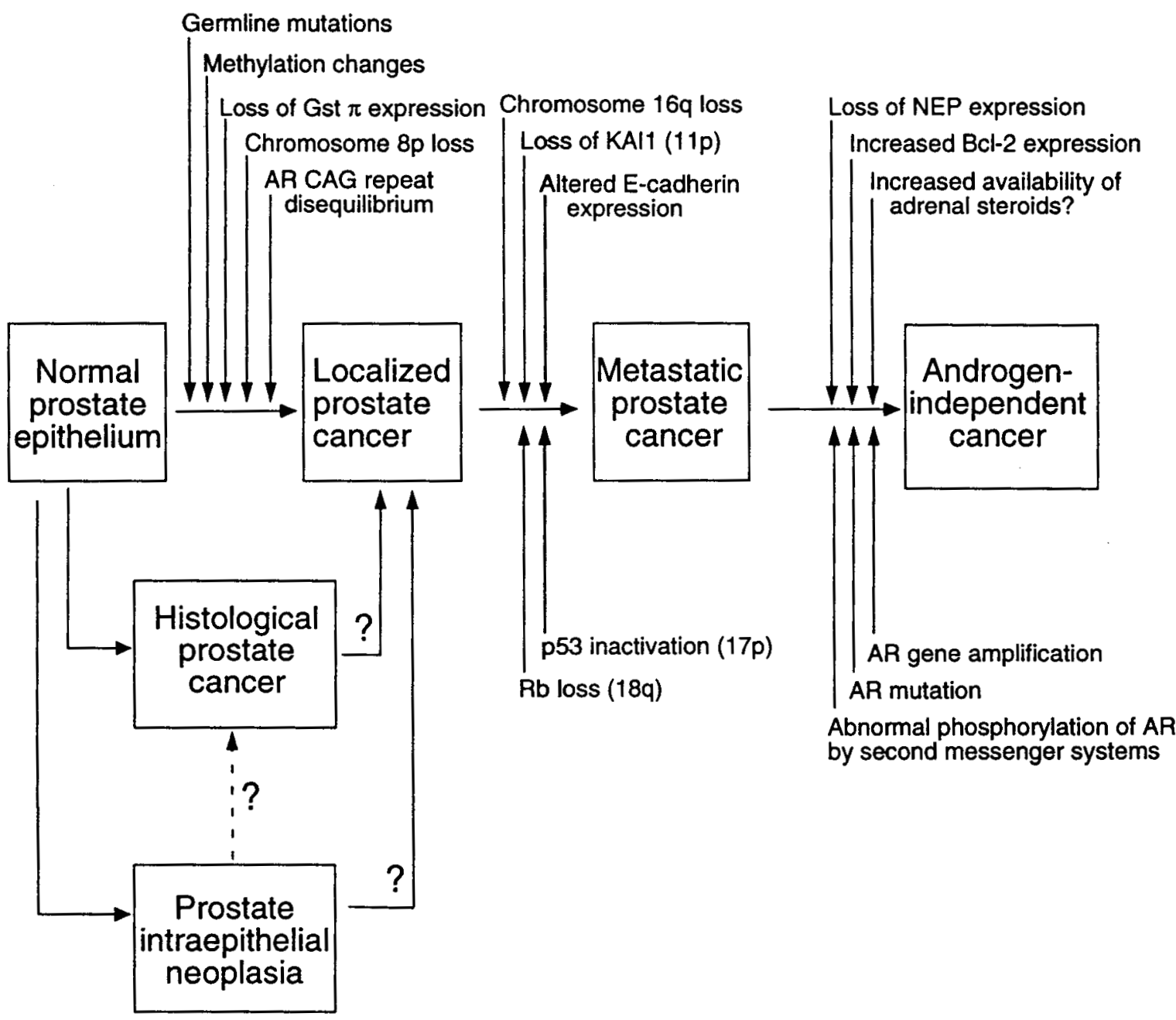

Figure 1. Genetic progression of prostate cancer carcinogenesis. The postulated progression of a normal prostate epithelium to an androgen independent invasive phenotype. Chromosomal alterations, induction of oncogenes, loss/mutation of tumor suppressor genes, increased availability of adrenal steroids, loss of growth inhibiting neutral endopeptidase 24.11 (NEP) and genetic mutation/amplification/abnormal activation of androgen receptor (AR) are indicated.

tumor is initially heterogeneous in terms of androgen sensitivity.

\section{The role of the androgen receptor}

Androgens (testosterone and dihydrotestosterone) exert their actions by binding to the androgen receptor (AR). This receptor complex undergoes phosphorylation and dimerization to become an activated complex which is now capable of binding tightly to specific
DNA sequences (termed androgen response elements or AREs). Once bound to DNA, this complex facilitates the formation of a preinitiation complex on the promoter of target genes and enhances transcription. The induction of these target genes can then lead to translation of new proteins which may initiate some biological response (i.e. growth).

The role of androgen receptor (AR) gene mutations in the progression of prostate cancer to a hormone independent state has been more widely studied than any other molecular mechanism [5]. The AR protein can be 
divided into three regions: the amino terminal domain, which affects transcriptional efficiency; a central DNA binding domain, which binds to the ARE upstream of target genes; and the hormone binding domain [6]. Many of the mutations found in the AR gene target the hormone binding region (reviewed in [5-7]). Whereas increased transcriptional activity is only observed when the wildtype AR protein is bound to androgens, many of these mutated receptors have the ability to increase transcriptional activity when bound to other steroid hormones such as progestins, estrogens or even antiandrogens (reviewed in $[5,6]$ ). This would enable the tumor cells to utilize the androgen receptor machinery for induction of growth by responding to other endogenous steroid hormones. This is of direct clinical concern, as prescribing standard anti-androgen therapy to patients with mutations in the AR gene, may allow for transcriptional activation by anti-androgens and could be detrimental to their treatment [8]. It should be noted, however, that although there is substantial evidence demonstrating mutations of the AR gene, the frequency and role of these mutations remains unclear. There has been speculation that AR mutations may characterize a more aggressive disease or confer the ability of hormone independence [6]. However, as there have been a number of studies demonstrating no mutations in the AR gene of patients with hormone refractory prostate cancer, the current evidence does suggest that not all hormone-independent cancers contain AR gene mutations.

AR gene expression has been examined by a number of groups both in vitro and in vivo [7,9-12]. Initial studies using the Dunning rat prostate adenocarcinoma model and the human prostate cancer cell lines DU145 and PC3 suggested a decrease in both AR mRNA and protein levels $[9,10]$. More recent studies, however, contradict these findings. AR protein has been detected immunohistochemically in the majority of human prostate cancers, regardless of disease state $[11,12]$. Androgen ablation therapy does not appear to significantly change the pattern of AR expression, suggesting that failure of androgen ablation therapy is not due to the selection of AR-negative tumor cells $[11,12]$. Moreover, a study by Visakorpi and colleagues has demonstrated that a common genetic alteration in hormone refractory, locally recurrent prostate cancers was an amplification of the chromosomal region Xq1112 , which coincides with the location of the androgen receptor gene $[5,13]$. Further studies demonstrated a 2.7 to 28 fold amplification in 15 out of 54 locally recurrent tumors, whereas no amplification was observed in the primary tumors examined $[5,13]$. These results suggest that perhaps many recurrent prostate tumors may not be androgen independent as previously thought, but may have acquired an increased capacity, due to the increased number of receptors, to utilize residual androgens which remain after ablation therapy [5].

\section{Increased availability of androgens}

Another mechanism which could allow for growth of prostate tumor cells after androgen ablation therapy involves the increased availability of adrenal steroids in the prostate [5]. It has been demonstrated that although castration-induced androgen deprivation causes a $95 \%$ loss in serum testosterone, the concentration of dihydrotestosterone (DHT) in prostate tissue is only reduced by $60 \%$ [14]. It is possible that after androgen ablation therapy there is an increased conversion of adrenal steroids to active androgens, which would allow for androgen-dependent growth of the tumor. The combination of traditional endocrine therapy (gonadotropin hormone releasing hormone agonists, estrogens or surgical castration) and anti-androgen therapy (flutamide, nilutamide or bicalutamide) which would block androgen production in peripheral tissues has been suggested as the most effective therapy. Current clinical evidence, however, gives only minimal support of the benefit of maximum androgen blockage therapy [15].

\section{Differential gene expression}

There are a number of groups which are examining the genetic differences between hormone-dependent and hormone-independent prostate cancers [16-19]. Although there have been a number of differences found, the identity and mechanism of many of these genes are unknown [16-19]. One recent finding by Papandreou and colleagues, however, demonstrated the loss of expression of neutral endopeptidase 24.11 (NEP) in hormone refractory cancers. NEP is a cellsurface enzyme expressed by prostatic epithelial cells that cleaves and inactivates neuropeptides such as neurotensin, bombesin and endothelin-1, all which have been implicated in the growth of androgen-dependent prostate cancer [20-23]. NEP appears to be diminished in androgen-independent prostate cancer cell lines and in the majority $(78 \%)$ of metastatic prostate cancer 
specimens examined [20]. Androgen ablation therapy would allow an increase in the bioavailability of mitogenic neuropeptides, suggesting another mechanism for growth of hormone refractory prostate cancer [20].

Many of the androgen mediated growth processes appear to be the result of the secretion of local paracrine factors by the prostatic stroma [24]. There is substantial evidence demonstrating the increased expression of growth factors, their receptors and binding proteins during the progression of prostate cancer [5,25-29]. Members of the fibroblast growth factor (FGF) and insulin-like growth factor (IGF) families as well as transforming growth factor $\alpha$ and keratinocyte growth factor, have been shown to activate the AR signaling pathway in the absence of androgens (reviewed in [5]). Transforming growth factor $\beta$ has also been shown to be overexpressed in more advanced tumors, suggesting an aberrant activity for this growth factor (reviewed in [8]). Finally, there is increasing evidence that AR can be activated in the absence of androgens by ligandindependent phosphorylation of the AR through the protein kinase A signaling pathway [30].

\section{Alternative mechanisms}

There are many other alternative mechanisms which may contribute to prostate tumor cells no longer requiring androgens for growth. For instance, steroids interact with a number of accessory factors to bring about optimal transcription of target genes. The ARA-70 protein has been shown to be a specific coactivator of the AR complex, enhancing transcription by a factor of ten [31]. Under appropriate conditions this transcription factor may allow activation of androgen specificgrowth enhancing genes in the absence of androgens.

Alternatively, androgen withdrawal causes regression of prostate cells by triggering the apoptotic pathway [32]. Bcl-2, a protein which inhibits apoptosis, has been shown to increase in prostate cancer [33-35]. Androgen-independent tumors demonstrate a much higher level of expression of bcl-2 protein [35]. This increase in bcl-2 levels may create an apoptosisresistant cell population which is capable of androgenindependent growth.

Finally, the p53 tumor suppressor gene is believed to be a negative regulator of cell growth [36,37]. p53 mutations appear to be a late event in the progression of prostate cancer, with tumors of higher grade and stage demonstrating a higher frequency of mutations of this gene. Also, it has been demonstrated that androgen-independent tumors have a high degree of p53 mutations [36]. Whether these mechanisms contribute to the growth of androgen-independent tumors remains to be seen.

\section{Current treatments for hormone refractory prostate cancer (HRPC)}

Prostate cancer that progresses in the presence of androgen blockade (i.e. castrate levels of testosterone) is defined as hormone refractory prostate cancer (HRPC). No effective 'standard' chemotherapy exists for these patients, in which median survival is 6-9 months [38]. The National Comprehensive Cancer Network (NCCN), an organization of cancer centers around the country, recently updated its practice guidelines for the treatment of patients with HRPC [39]. These guidelines, for patients managed outside of experimental protocol, list three different categories of care: supportive care with prednisone, palliative chemotherapy and/or systemic radiation (Table 1).

\section{Supportive care}

As clinical trials have yet to demonstrate a therapeutic combination which has been shown to definitively increase survival, a reasonable alternative to other treatments of HRPC is supportive care. Supportive care should consist of rigorous pain management, symptom control and include active hospice care [40]. Prednisone and other glucocorticoids have frequently been used to manage symptoms in patients who have advanced prostate cancer with a number of studies documenting improved symptom control and increased quality of life in treated patients [41-43]. Concomitantly, the role of bisphosphonates in palliating bone pain is also beginning to be appreciated [44].

\section{Chemotherapy}

Chemotherapy is an option in the treatment of advanced prostate cancer. The NCCN guidelines recommend several regimens that can be used (Table 1). Briefly, the first regimen consists of ketoconazole and doxorubicin. This combination has been evaluated in a phase II trial with patients whose disease had progressed following initial hormone therapy (results summarized in Table 1) [45]. Complications included the development 
Table 1. $\mathrm{NCCN}^{\mathrm{a}}$ Treatment guidelines for hormone refractory prostate cancer

\begin{tabular}{|c|c|c|c|c|c|}
\hline Regimen & Schedule & $\begin{array}{l}\text { Pain control } \\
(\%)^{\mathrm{b}}\end{array}$ & $\begin{array}{l}\text { Meas. disease } \\
\text { resp. }(\%)^{\mathrm{e}}\end{array}$ & $\begin{array}{l}\text { PSA } \\
\text { response }(\%)^{\mathrm{f}}\end{array}$ & Reference \\
\hline \multicolumn{6}{|l|}{ Supportive care } \\
\hline Prednisone & $7.5-10 \mathrm{mg} / \mathrm{d}^{\mathrm{c}}$ & 40 & & & {$[42]$} \\
\hline Dexamethasone & $0.75 \mathrm{mg} \mathrm{bid}^{\mathrm{d}}$ & 63 & & & [43] \\
\hline \multicolumn{6}{|l|}{ Chemotherapy } \\
\hline Ketoconazole & $1200 \mathrm{mg} / \mathrm{d}$ & & & & \\
\hline Doxorubicin & $20 \mathrm{mg} / \mathrm{m}^{2} \mathrm{IV}$ over $24 \mathrm{~h}$ each week & & 58 & 55 & {$[45]$} \\
\hline Vinblastine & $4 \mathrm{mg} / \mathrm{m}^{2} / \mathrm{wk}$ for $6 \mathrm{wk}$ & & & & \\
\hline Estramustine & $600 \mathrm{mg} / \mathrm{m}^{2} / \mathrm{d}$ for $42 \mathrm{~d}$ & & $14-40$ & $54-61$ & {$[48-50]$} \\
\hline Etoposide & $50 \mathrm{mg} / \mathrm{m}^{2} / \mathrm{d}$ for $21 \mathrm{~d}$ & & & & \\
\hline Estramustine & $10 \mathrm{mg} / \mathrm{kg} / \mathrm{d}$ for $21 \mathrm{~d}$ & & $45-53$ & $39-58$ & {$[51-53]$} \\
\hline Paclitaxel & $120 \mathrm{mg} / \mathrm{m}^{2} \mathrm{IV}$ over $96 \mathrm{~h}$ every $3 \mathrm{wk}$ & & & & \\
\hline Estramustine & $600 \mathrm{mg} / \mathrm{m}^{2} / \mathrm{d}$ continuously & & 44 & 53 & {$[58]$} \\
\hline Mitoxantrone & $12 \mathrm{mg} / \mathrm{m}^{2} \mathrm{IV}$ every $21 \mathrm{~d}$ & & & & \\
\hline Prednisone & $5 \mathrm{mg}$ bid & & $\mathrm{NA}^{\mathrm{g}}$ & 33 & {$[64]$} \\
\hline \multicolumn{6}{|l|}{ Radiotherapy } \\
\hline Standard external beam radiation & & & & & {$[66]$} \\
\hline Strontium-89 & & & & & {$[67-71]$} \\
\hline
\end{tabular}

of significant acral erythema and stomatitis in $29 \%$ of patients and an overall $45 \%$ hospitalization rate.

The combination of vinblastine and estramustine is another chemotherapeutic approach in the treatment of HRPC. While vinblastine alone yields minimal response as a single agent in HRPC, the combination with estramustine has demonstrated synergistic effects in both preclinical and clinical studies (clinical data summarized in Table 1) [46-50]. The therapy appears to be well tolerated with minimal complications.

The third regimen utilizes a combination of estramustine and etoposide. Both these agents exert an effect through the nuclear matrix [51]. Both in vitro and in vivo preclinical studies demonstrate that the combination of these agents was more effective than either agent alone [51]. These studies formed the basis for several clinical trials [52-54]. Combined results of three trials (with lower doses of estramustine in each consecutive trial) demonstrated soft tissue responses in $45-53 \%$ of patients; PSA declines of greater than $50 \%$ in $39-58 \%$ and a median survival of 52-56 weeks. Estramustine can cause significant nausea with the regimen reported to be more tolerable in the two trials with decreased estramustine doses [53,54].

A fourth regimen combines estramustine with paclitaxel. While both of these agents demonstrate antimicrotubule activity, each possess different mechanisms of action. While clinical studies with paclitaxel alone proved disappointing [55], the combination of paclitaxel with estramustine demonstrated synergistic responses in both preclinical and clinical studies (Table 1) [56-58]. Preliminary analysis of a phase II trial combining estramustine and etoposide with paclitaxel $\left(135 \mathrm{mg} / \mathrm{m}^{2}\right.$ over $3 \mathrm{~h}$ on day 2$)$ showed an improved response compared to estramustine and etoposide alone and similar response to the results 
obtained with the combination of paclitaxel and estramustine $[59,60]$.

The fifth regimen is a combination of the semisynthetic doxorubicin-derivative mitoxantrone with prednisone. Preliminary clinical studies with mitoxantrone alone demonstrated modest activity with the drug being well tolerated [61,62]. These observations led to two trials of mitoxantrone in HRPC in which palliative endpoints were used as response criteria $[63,64]$. One trial compared the combination of mitoxantrone with prednisone with prednisone alone (Table 1) [64]. Twenty-nine percent of the patients in the mitoxantrone-prednisone arm achieved the defined palliative endpoints whereas only $12 \%$ of the patients in the prednisone arm reported these responses [64]. Patients who demonstrated a response had significant improvement in quality of life scales measuring overall well-being.

\section{Radiotherapy}

The majority of patients with HRPC do not have softtissue disease. Rather they experience bone metastases. Autopsy studies conducted on patients with advanced prostate cancer have documented the frequency of bone metastasis at being $65-85 \%$ [65]. The hallmark of skeletal metastasis is pain. The main goal of therapy for these patients is symptom control. Standard external-beam radiation therapy, which has been shown to be effective in controlling symptoms in a regionally treated area, is not a likely treatment option for patients with diffuse bone metastases. Injectable radioisotopes have been investigated. Phosphorous 32 was shown to be effective in achieving pain relief; however, significant bone marrow depression limited its clinical use (Table 1) [66]. More promising is the use of strontium89 , which localizes preferentially to sites of osteoblastic activity. This minimizes the myelosuppressive effect of therapy. Strontium- 89 has been tested in a number of clinical trials with promising results [67-71]. Patients reported symptom relief, as well as increased mobility and improved quality of life [67-71].

\section{Conclusions}

Androgen resistance is the inevitable outcome for prostate cancer that is treated with androgen deprivation. The switch to an androgen resistant phenotype appears to be the result of the growth of resistant cells already present at the initiation of therapy. This phenotype has been associated with multiple changes at the molecular level. None of these alterations, however, have been universally demonstrated in hormone refractory tumors. Most likely it is the accumulation, as well as the yet to be described synergism, of these and other genetic alterations that lead to the androgen resistant phenotype. Treatment regimens for this disease are promising. Currently, there are practical, effective and tolerable regimens for HPRC available. Many regimens (too numerous to be discussed here) are currently being tested in preclinical and clinical settings with promising results. Hopefully, these approaches will soon provide new and improved treatments for patients with hormone refractory prostate cancer.

\section{Acknowledgements}

This was supported by Bristol-Meyers Squibb Oncology, CaPCURE and SPORE grant P50 CA 69568. Dr. Pilat is supported by an American Foundation for Urological Disease Ph.D. Research Fellowship.

\section{References}

1. Landis SH, Murray T, Bolden S, Wingo PA: Cancer Statistics, 1999. CA Cancer J Clin 49: 6-29, 1999

2. Isaacs JT, Coffey DS: Adaptation versus selection as the mechanism responsible for the relapse of prostatic cancer to androgen ablation therapy as studied in the Dunning R-3227-H adenocarcinoma. Cancer Res 41: 5070-75, 1981

3. Gingrich JR, Barrios RJ, Morton RA, Boyce BF, DeMayo FJ, Finegold MJ, Angelopoulou R, Rosen JM, Greenberg NM: Metastatic prostate cancer in a transgenic mouse. Cancer Res 56: 4096-102, 1996

4. Gingrich JR, Barrios RJ, Kattan MW, Nahm HS, Finegold MJ, Greenberg NM: Androgen-independent prostate cancer progression in the TRAMP model. Cancer Res 57: 4687-91, 1997

5. Kovisto P, Kolmer M, Visakorpi T, Kallioniemi OP: Androgen receptor gene and hormonal therapy failure of prostate cancer. Am J Pathol 152: 1-9, 1998

6. Barrack ER: Androgen receptor mutations in prostate cancer. Mount Sinai J Med 63: 403-12, 1996

7. Tilley WD, Buchanan G, Hickey TE, Bentley JM: Mutations in the androgen receptor gene are associated with progression of human prostate cancer to androgen independence. Clin Cancer Res 2: 277-85, 1996

8. Dorkin TJ, Robson CN, Neal DE: The molecular pathology of urological malignancies. J Pathology 183: 380-87, 1997 
9. Quarmby VE, Beckman WC Jr, Cooke DB, Lubahn DB, Joseph DR, Wilson EM: Expression and localisation of androgen receptor in the R-3327 Dunning rat prostatic adenocarcinoma. Cancer Res 50: 735-39, 1990

10. Tilley WD, Wilson CM, Marcelli M, McPhaul MJ: Androgen receptor gene expression in human prostate carcinoma cell lines. Cancer Res 50: 5382-86, 1990

11. Bentel JM, Tilley WD: Androgen receptors in prostate cancer. J Endocrinol 151: 1-11, 1996

12. Van der Kwast TH, Schalken J, Ruizeveld de Winter JA, van Vroohoven CC, Mulder G, Boersman W, Trapman J: Androgen receptors in endocrine therapy-resistant human prostate cancer. Int J Cancer 48: 189-93, 1991

13. Visakorpi T, Hyytinen E, Kovisto P, Tanner M, Keinanen R, Palmber C, Palotie A, Tammela T, Isola J, Kallioniemi OP: In vivo amplification of the androgen receptor gene and progression of human prostate cancer. Nature Genetics 9: 401-6, 1995

14. Labrie F, DuPont A, Balanger A, St-Arnaud R, Giguere M, Lacourciere Y, Emond J, Monfette G: Treatment of prostate cancer with gonadotropin-releasing hormone agonists. Endocrine Rev 7: 67-74, 1986

15. Crawford ED, DeAntoni EP, Hussain M, Thompson IM, Coltman CA: Prostate cancer clinical trials of the southwest oncology group. Oncology 11; 1154-63, 1997

16. Blok LJ, Kumar V, Tindall DJ: Isolation of cDNAs that are differentially expressed between androgen-dependent and androgen-independent prostate adenocarcinoma cells using differential display PCR. Prostate 26: 213-24, 1995

17. Chang GT, Blok LJ, Steenbeek M, Veldscholte J, van Weerden WM, van Steenbrugge GJ, Brinkmann AO: Differentially expressed genes in androgen-dependent and -independent prostate carcinomas. Cancer Res 57: 4075-81, 1997

18. Schwab ED, Choeypunt N, Pienta KJ: Identification of genes involved in prostate cancer metastasis by mRNA differential display. Proc Amer Assoc Cancer Res 37: 86, 1997

19. Schwab ED, Pienta KJ: Identification of two genes associated with metastatic prostate cancer. Proceedings of the Am Urolog Ass 93rd meeting: 1, Abstract \#2, 1998

20. Papandreou CN, Usmani B, Geng Y, Bogenrieder T, Freeman R, Wilk S, Finstad CL, Reuter VE, Powell CT, Scheinberg D, Magill C, Scher HI, Albino AP, Nanus DM: Neutral endopeptidase 24.11 loss in metastatic human prostate cancer contributes to androgen-independent progression. Nature Med 4: 50-7, 1998

21. Bologna M, Festuccia C, Muzi P, Biordi L, Ciomei M: Bombesin stimulates growth of human prostatic cancer cells in vitro. Cancer 63: 1714-20, 1989

22. Nelson JB, Chan-Tack K, Hedican SP, Magnuson SR, Opgenorth TJ, Bova GS, Simons JW: Endothelin-1 prodution and decreased endothelin B receptor expression in advanced prostate cancer. Cancer Res 56: 663-68, 1996

23. Sehgal I, Powers S, Huntley B, Powis G, Pittelkow M, Maihle NJ: Neurotensin is an autocrine trophic factor stimulated by androgen withdrawal in human prostate cancer. Proc Natl Acad Sci USA 91: 4673-77, 1994

24. Dorkin TJ, Robson CN, Neal DE: The molecular pathology of urological malignancies. J Pathology 183: 380-87, 1997
25. Figueroa JA, DeRaad S, Tadlock L, Speights VO, Rinehart JJ: Differential expression of insulin-like growth factor binding proteins in high versus low Gleason score prostate cancer. J of Urol 159: 1379-83, 1998

26. Fong C-J, Sherwood ER, Mendelsohn J, Lee C, Kozlowski J: Epidermal growth factor receptor monoclonal antibody inhibits constitutive receptor phosphorylation, reduces autonomous growth, and sensitizes androgen-independent prostatic carcinoma cells to tumor necrosis factor- $\alpha$. Cancer Res 52: 5887-92, 1992

27. Hofer DR, Sherwood E, Bromberg WD, Mendelsohn J, Le C, Kozlowski J: Autonomous growth of androgenindependent prostatic carcinoma cells: role of transforming growth factor a. Cancer Res 51: 2780-85, 1991

28. Pietrzkowski Z, Mulholland G, Gomella L, Jameson BA, Wernicke D, Baserga R: Inhibition of growth of prostatic cancer cell lines by peptide analogues of insulin-like growth factor. Cancer Res 53: 1102-06, 1993

29. Rajah R, Valenitinis B, Cohen P: Insulin-like growth factor (IGF)-binding protein-3 induces apoptosis and mediates the effects of transforming growth factor- $\beta 1$ on programmed cell death through a p53- and IGF-independent mechanism. J Biol Chem 272: 12181-8, 1997

30. Nazareth LV, Weigel NL: Activation of the human androgen receptor through a protein kinase A signaling pathway. J Biol Chem 271: 19900-907, 1996

31. Yeh S, Chang C: Cloning and characterization of a specific coactivator, ARA 70, for the androgen receptor in human prostate cells. Proc Natl Acad Sci USA 93: 5517-21, 1996

32. Kyprianou N, Isaacs JT: Activation of programmed cell death in the rat ventral prostate after castration. Endocrinol 122: 552-62, 1988

33. Colombel M, Symmans F, Gil S, O'Toole KM, Chopin D, Benson M, Olsson CA, Korsmeyer S, Buttyan R: Detection of the apoptosis-suppressing oncoprotein bcl-2 in hormonerefractory human prostate cancers. Am J Pathol 143: 390400, 1993

34. Aihara M, Scardino PT, Truong LD, Wheeler TM, Goad JR, Yang G, Thompson TC: The frequency of apoptosis correlates with the prognosis of Gleason Grade 3 adenocarcinoma of the prostate. Cancer 75: 522-29, 1995

35. McDonnell TJ, Troncoso P, Brisbay SM, Logothetis C, Chung LW, Hsieh JT, Tu SM, Campbell ML: Expression of the protooncogene bcl-2 in the prostate and its association with emergence of androgen-independent prostate cancer. Cancer Res 52: 6940-44, 1992

36. Shi XB, Gumerlock PH, de Vere Whit RW: Molecular biology of prostate cancer. World J Urol 14: 318-28, 1996

37. Bookstein R, MacGrogan D, Hilsenbeck SG, Sharkey F, Allred DC: p53 is mutated in a subset of advanced-stage prostate cancers. Cancer Res 53: 3369-73, 1993

38. Kantoff PW. New agents in the therapy of hormonerefractory prostate cancer. Semin Oncol 22: 32-34, 1995

39. Millikan R, Logothetis C: Update of the NCCN guidelines for treatment of prostate cancer. Oncology 11: 180-93, 1997

40. Esper PS, Pienta KJ: Supportive care in the patient with hormone refractory prostate cancer. Semin Urol Oncol 15: 56-64, 1997 
41. Hamdy FC, Williams JL: Use of dexamethasone for ureteric obstruction in advanced prostate cancer: percutaneous nephrostomies can be avoided. Br J Urol 75: 782-85, 1995

42. Tannock I, Gospodarowicz Meakin W, Panzarella T, Stewart L, Rider W: Treatment of metastatic prostatic cancer with low-dose prednisone: evaluation of pain and quality of life as pragmatic indices of response. J Clin Oncol 7: 590-97, 1989

43. Storlie JA, Buckner JC, Wiseman GA, Burch PA, Hartmann LC, Richardson RL: Prostate specific antigen levels and clinical response to low dose dexamethasone for hormone-refractory metastatic prostate carcinoma. Cancer 76: 96-100, 1995

44. Adami S: Bisphosphonates in prostate cancer. Cancer 80: 1674-79, 1997

45. Sella A, Kilbourn R, Amato R, Bui C, Zukiwski AA, Ellerhorst J, Logothetis CJ: Phase II study of ketoconazole combined with weekly doxorubicin in patients with androgen-independent prostate cancer. J Clin Oncol 12: 683-88, 1994

46. Dexeus F, Logothetis CJ, Samuels ML, Hossan E, Von Escherbach AC: Continuous infusion of vinblastine for advanced hormone-refractory prostate cancer. Cancer Treat Rep 69: 885-86, 1985

47. Batra S, Karlsson R, Witt L: Potentiation by estramustine of the cytotoxic effect of vinblastine and doxorubicin in prostatic tumor cells. Int J Cancer 68: 644-49, 1996

48. Hudes GR, Greenberg R, Kriegel RL, Fox S, Scher R, Litwin S, Watts P, Speicher L, Tew K, Comis R: Phase II study of estramustine and vinblastine, two microtubule inhibitors, in hormone-refractory prostate cancer. J Clin Oncol 10: 1754-61, 1992

49. Seidman AD, Scher HI, Petrylak D, Dershaw DD, Curley T: Estramustine and vinblastine: use of prostate specific antigen as a clinical trial endpoint for hormone refractory prostatic cancer. J Urol 147: 931-34, 1992

50. Attivissimo LA, Fetten JV, Kreis W: Symptomatic improvement associated with combined estramustine and vinblastine chemotherapy for metastatic prostate cancer. Am J Clin Oncol 19: 581-83, 1996

51. Pienta KJ, Lehr JE: Inhibition of prostate cancer growth by estramustine and etoposide: evidence for interaction at the nuclear matrix. J Urol 149: 1622-25, 1993

52. Pienta KJ, Redman B, Hussain M, Cummings G, Esper PS, Appel C, Flaherty LE: Phase II evaluation of oral estramustine and oral etoposide in hormone-refractory adenocarcinoma of the prostate. J Clin Oncol 12: 2005-12, 1994

53. Pienta KJ, Redman BG, Bandekar R, Strawderman MA, Cease K, Esper PS, Naik H, Smith DC: Phase II trial of oral estramustine and oral etoposide in hormone refractory prostate cancer. Urology 50: 401-07, 1997

54. Dimopoulos MA, Panopoulos C, Bamia C, Deliveliotis C, Alivizatos G, Pantazopoulos D, Constantinidis C, Kostakopoulos A, Kastriotis I, Zervas A, Aravantinos G, Dimopoulos C: Oral estramustine and oral etoposide for hormone-refractory prostate cancer. Urology 50: 754 58, 1997

55. Roth BJ, Yeap BY, Wilding G, Kasimis B, McLeod D, Loerher PJ: Taxol in advanced, hormone-refractory carcinoma of the prostate. A phase II trial of the Eastern Cooperative Oncology Group. Cancer 72: 2457-60, 1993

56. Pienta KJ, Naik H, Lehr JE: Effect of estramustine, etoposide and taxol on prostate cancer cell growth in vitro and in vivo. Urology 48: 164-70, 1996

57. Speicher LA, Barone L, Tew KD: Combined antimicrotubule activity of estramustine and taxol in human prostatic carcinoma cell lines. Cancer Res 52: 4433-40, 1992

58. Hudes GR, Nathan F, Khater C, Haas N, Cornfield M, Giantonio B, Greenberg R, Gomella L, Litwin S, Ross E, Roethke S, McAleer C: Phase II trial of 96-hour paclitaxel plus oral estramustine phosphate in metastatic hormonerefractory prostate cancer. J Clin Oncol 15: 3156-63, 1997

59. Smith DC, Esper PS, Todd III RT, Pienta KJ: Paclitaxel plus estramustine in metastatic hormone-refractory prostate cancer. Proc Annu Meet Am Soc Clin Oncol 16: 1105 (Abstract), 1997

60. Kamradt JM, Smith DC, Pienta KJ: Hormone-refractory prostate cancer: national comprehensive cancer network guidelines. Adv Onc 14: 14-21, 1998

61. Osborne CK, Drelichman A, Von Hoff DD, Crawford ED: Mitoxantrone: modest activity in a phase II trial in advanced prostate cancer. Cancer Treat Rep 67: 1133-35, 1983

62. Kantoff PW, Block C, Letvak L, George M: 14-day continuous infusion of mitoxantrone in hormone-refractory metastatic adenocarcinoma of the prostate. Am J Clin Oncol 16: 489-91, 1993

63. Moore MJ, Osoba D, Murphy K, Tannock IF, Armitage A, Findlay B, Coppin C, Neville A, Venner P, Wilson J: Use of palliative end points to evaluate the effects of mitoxantrone and low-dose prednisone in patients with hormonally resistant prostate cancer. J Clin Oncol 12: 689-94, 1994

64. Tannock IF, Osoba D, Stockler MR, Ernst DS, Neville AJ, Moore MJ, Armitage GR, Wilson JJ, Venner PM, Coppin CML, Murphy KC: Chemotherapy with mitoxantrone plus prednisone or prednisone alone for symptomatic hormone-resistant prostate cancer: A Canadian randomized trial with palliative endpoints. J Clin Oncol 14: 1756-64, 1996

65. Kozlowski JM, Ellis WJ, Grayhack JT: Advanced prostatic carcinoma - early versus late endocrine therapy. Urol Clin North Am 18: 15-24, 1991

66. Silberstein EB: The treatment of painful osseous metastases with phosphorous-32 labeled phosphates. Semin Oncol (20 No 3 Suppl 2): 10-21, 1993

67. Robinson RG, Blake GM, Preston DF, McEwan AJ, Spicer JA Martin NL, Wegst AV, Ackery DM: Strontium89 treatment results and kinetics in patients with painful metastatic prostate and breast cancer in bone. Radiographics 9: 271-81, 1989

68. McEwan AJB, Porter AT, Venner PM, Amyotte G: An evaluation of the safety and efficacy of treatment with strontium-89 in patients who have previously received wide field radiotherapy. Antibody Immunoconjugates Radiopharm 3: 91-96, 1990

69. Lewington VJ, McEwan AJ, Ackery DM, Bayly RJ, Keeling DH, Macleod PM, Porter AT, Zivanovic MA: A prospective randomised double-blind crossover study to determine the efficacy of strontium- 89 in pain palliation in 
patients with advanced prostate cancer metastatic to bone. Eur J Cancer 27: 954-58, 1991

70. Laing AH, Ackery DM, Bayly RJ, Buchanan RB, Lewington VJ, McEwan AJ, Macleod PM, Zivanovic MA: Strontium-89 for pain palliation in prostatic skeletal malignancy. Br J Radiol 64: 816-22, 1991

71. Porter AT, McEwan AJ, Powe JE, Reid R, McGowan DG, Lukka H, Sathyanarayana JR, Yakemchuk VN, Thomas GM, Erlich LE: Results of a randomized phase III trial to evaluate the efficacy of strontium- 89 adjuvant to local filed external beam irradiation in the management of endocrine resistant metastatic prostate cancer. Int J Radiat Oncol Biol Phys 25: 805-13, 1993

Address for offprints: Kenneth J. Pienta, University of Michigan Medical School, Department of Internal Medicine, 1500 East Medical Center Dr.7303 CCGC, Ann Arbor, MI 48109-0946, USA; Tel: 7346473421 ; Fax: 734647 9480; e-mail: kpienta@umich.edu 